\title{
The effectiveness of a training program based on active learning strategies among students of the College of Basic Education and their logical thinking
}

\author{
Wafa Abd Al-Razzaq Abbas Al-Anabi \\ Babylon University / College of Basic Education
}

Dr.Saeed Hussain Ali Al-Thallab

University of Babylon / College of Basic Education / Department of Mathematics and Computer. saeedalthallab@yahoo.com

\begin{abstract}
:
The aim of the current research is to identify (the effectiveness of the training program based on active learning strategies among students of the College of Basic Education and their logical thinking, and to achieve the goal of the research, the experimental design with partial control was used for two equivalent groups, one experimental and the other a control. The research sample was chosen randomly from the research community and the number of the sample was selected) 80) male and female students, where the training program was applied to the members of the experimental group after the researcher built and prepared it by reviewing the studies and special resources in building programs as well as the literature on active learning and its strategies, as well as building and preparing the test for logical thinking, Where it was applied to all the research sample after the completion of the training program on the experimental group, which was for a period of (12) weeks in the first semester of the year (2019-2020), and the researcher reached a set of results through which conclusions, recommendations and proposals that feed the field were drawn Educational information that helps the development of the educational progress process.
\end{abstract}

Keywords:

program, training, logical thinking, students

Article Received: 18 October 2020, Revised: 3 November 2020, Accepted: 24 December 2020

\section{Chapter one}

First: the research problem:

From Bean (DeBono), citing Jabr, 2008) “A person is nothing but his own thinking in which he sees the activity of the mind or the effectiveness of arriving at a decision. (Jabr, 2008, p. 25). Logical reasoning is a type of thinking that has received widespread attention in most educational writings. Likewise, interest in modern research studies is because it is one of the characteristics that distinguishes a person from other organisms (Ahmad, 2004, p. 4).

For the purpose of keeping pace with development and cognitive changes, we must have thinking students. In this case, we must teach him thinking skills through a set of clear steps that are appropriate to his stage of development and mental capabilities. This may not be achieved in the teaching methods prevailing in education, as they do not pay attention to mental skills. Logical thinking, as it saves information and retrieval without concern for questions and activities that require thinking.

The researcher believes, through her modest experience of (15) years, as she supervised student teachers during the period of their application specified in the second semester of each year that the methods adopted by students are hardly different from the methods of lecturing and interrogation that provide opportunities for students to practice thinking activities. The study (Al-Sheikh, 2015) also indicated that teacher preparation programs are characterized by the reluctance of faculty members to use modern teaching methods that include thinking skills and patterns (Al-Sheikh, 2015, p. 3).

Therefore, we can define the research problem in answering the following question:

"The effectiveness of the training program based on active learning strategies among students of the 
College of Basic Education and their logical thinking?"

Second: - The importance of research:

1- The importance of training programs designed to train (students - teachers) on logical thinking skills, with the aim of preparing a thinking generation.

2- Thinking skills education programs are not linked to a specific curriculum, but rather complementary to textbooks and curricula. Because thinking is a strong pillar and a continuous force for the survival of the individual and society together in today's and tomorrow's world.

3- The current study is one of the field studies that seek statistical verification of the validity of the administration used in the study in the absence of similar studies within the limits of the researcher's knowledge.

4- It is a call for the use of Arab-designed tests and standards (departments) and to ensure their validity along the lines of foreign departments.

5- Students' use of logical thinking and its skills lead to a deeper understanding of academic topics. It also links these topics with each other in a harmonious way that helps in effective learning.

Third: - Research objective:

- Building a training program based on active learning strategies for students of the College of Basic Education in logical thinking.

The goal of the research can only be achieved by formulating the following null hypothesis:

1 - There is no statistically significant difference at the level of significance (0.05) between the average scores of students who were trained and the average scores of students who were not trained (not subject to) the proposed training program in the logical thinking test.

Fourth: Research Limits:

1- Human Frontiers:

- Fourth stage students / Chemistry Branch / Science Department / College of Basic Education

- University of Babylon for the academic year (2020-2021).

2- Knowledge boundaries:
- The five active learning strategies were presented and trained in the proposed training program.

- An overview of active learning in terms of importance, principles, fundamentals, and the roles of both the teacher and the learner.

3- Spatial boundaries:

University of Babylon / College of Basic Education / Department of Science / Chemistry Branch in Hilla.

4- Temporal limits:

The first and second semesters of the academic year $(2019 / 2020)$.

Fifthly: - Defining terms:

First: - The training program:

Zayed and Others, 2013.

An integrated system of educational content in which we organize knowledge, operations, skills, features, activities and teaching strategies that guide the growth of developing knowledge and thinking skills of trainees in order to improve their level of achievement and their capabilities in finding appropriate solutions to a problem directed to them "(Zayed and others, 2013, p. 21). Procedural definition by the researcher:

A plan that includes providing a set of organized and planned information, activities and experiences to train students under research and help them to develop their experiences and raise their abilities and thinking, which can be measured through the application of the logical reasoning test that the researcher built and prepared for the purpose of this study.

Second: - logical thinking:

Abu Ghali (2010).

"The ability of the student to think in order to reach a sign that supports or rejects a particular point of view through the ability to collect, preserve and organize information, then analyze, generate and evaluate it" (Abu Ghaly, 2010, p.11). Procedural definition by the researcher:

"The ability of students to respond quickly to reach results that support or reject a particular opinion through the ability to collect, preserve and 
organize information, then analyze, generate and evaluate it, and it is measured by the grades that students obtain in the test prepared by the researcher for this purpose.

\section{Chapter II}

First: - Training:

Training works to provide the individual with the methods, experiences, and practical and scientific directions necessary to use the knowledge and skills that he or she possesses. In order to evaluate the best possible performance in his job or to perform future tasks for training needs.

(Fever, 1991, p. 15).

Training objectives:

1- Teaching and training teachers before and after the profession with the skills required by the profession.

2- Performing the work required of them at a good level and with less effort.

3- Learn new methods that increase the proficiency of the profession.

4- Helping students, teachers, before graduation, to learn about laws and regulations that enable them to face new situations in the field of work.

5- Adding new experiences to students - teachers in their field of specialization and enlightening them about the daily educational problems that they may face.

Training methods:

First: According to the methods of its use and the purpose of its use (Li Yati, 2012, p. 44)

1- News methods that aim to increase the knowledge and information of the trainees, such as lectures, seminars, seminars.

2- Observation methods and their aim is to develop capabilities and skills, such as roleplaying, field visits, pictures, drawings.

3- Working methods aim to test the behavior and attitudes of the trainees and improve their performance.

Second: - According to the training methods during the preparation of students - teachers into four methods.
1- The theoretical training method: It includes the guided lecture and seminar, generating ideas.

2- Practical training method: it includes case study, role play, model practical lesson.

3- Self-training method: It includes the workshop and laboratories.

4- Training method in programmed education: It includes the use of: educational television and recording devices.

Second: Active Learning:

Theoretical foundations of learning activity:

The call for the adoption of active learning in teaching methods and teaching methods is one of the most common and widespread calls among educators, especially with the beginning of the twenty-first century after the emergence of constructivism as a philosophy and theory in education because active learning has a share in what some consider it the other side of constructivism: Active learning is based on the approach The constructive one who emphasizes that the person is the one who shapes his cognitive structure and who makes adjustments to him in light of what is happening in terms of developments. This means that the educational process is an internal process based on the activity of the individual and his positive interaction with learning situations (Attiyah, 2016, p. 232).

Active learning also derives its theoretical foundation from cognitive theorists such as Paolo Freddy, whose main educational philosophy revolves around the idea that education becomes more effective when it is located within the student's own knowledge and worldview. (Amio Saeedi and Hoda, 2016, 24). Activity learning is based on the principle: that knowledge is not transmitted to the individual, but rather is his mental activity between them and makes it meaningful that links what is new to what is previous and its representation in his cognitive structure by discovering multiple links between old and new information and that the individual learns better when interacting with others (League, 2018, p.232).

* The concept of active learning: 
Active learning makes students able to acquire specific skills, knowledge and specific trends. It is an education that the student enjoys in immersion and integration, and thus transforming the educational process from an enjoyable partnership between the teacher and the student (Badir, 2012, p. 35).

Active Learning Components:

1- Articles and sources: that must be available and appropriate for the student's age.

2- Practice: It provides the student with the opportunity to explore, experiment and install.

3- Selection: the teacher chooses what he wants to teach, and what materials are needed to work.

4- Student language: The student describes in his own language what he is doing. He uses the language to reflect on his work and communicate with others, and his new experience is complemented by previous experience using the language.

5- Support for adults: The recognition of adults (teacher and parents) of the student's ability, and encouragement of thinking, creativity, and problem-solving. (Al-Janabi, 2018, p. 39)

6- Dialogue with the self: dialogue with the self occurs during the students 'thinking about the topic in terms of students asking themselves what should they think about? How do they feel about the topic? The teacher can also ask students to answer a specific scale prepared for the purpose of developing learning. At the same time, students can write about what they are learning and how they are learning.

7- Dialogue with others: In traditional learning, students get to read from the curriculum (curriculum) or listen to the teacher, and after that a partial dialogue. In the most effective and lively dialogue, it is when the teacher creates an open discussion on a specific topic within a small group.

8- Observation or encounter: this type occurs when the student watches or hears another person doing something related to what they are learning. 9- Experience: This is done through active learning for an activity that the student accomplishes, such as designing a Hencke, learning music, or criticizing his writing.

The Importance of Active Learning: (Awad, Majdi, 2010, p. 31)

1- It increases students' enthusiasm for receiving information and concepts well.

2- Increase student interaction with each other in the classroom.

3- The student develops positive attitudes towards educational content and towards himself and his fellow students.

4- It helps students to gain experience and selfesteem.

5- Students return to commitment values. (Rifai, 2012, p.63).

* Components of logical thinking:

1- The individual's knowledge of the results of business or activities.

2- Identify the reasons and causes behind the difficulty.

3- It aims to provide evidence to prove the alternatives assumed and to implement them in order to face the difficulty.

4- An intentional, targeted process aimed at obtaining the best answer to the questions raised by the mind.

5- It makes the individual active and effective and requires from him an organized and fair stock recorded in building the individual cognitive.

* Characteristics of logical thinking:

1- Proportional Inference: This reasoning requires the student to be able to infer the nature of the proportional relationship between more than one component using proportion and proportion.

2- Control of variables: It requires the student to be able to isolate the factors that affect a particular phenomenon from among a group of factors that he determines.

3- Relational inference: It requires the student to be able to understand the interrelationships between factors and then make decisions accordingly.

4- Probability reasoning: It requires the student to be able to study the quantitative relationships between the elements of a group or groups and 
determine the proportion of each of them, then compare the ratios and finally give certain possibilities.

5- Consensual reasoning: It requires the student's ability to do experimental or theoretical work to make the largest possible number of connections between the elements under study and provided that the links are organized and coordinated and not random or duplicate.

\section{(Al-Tamimi, and Zaid, 2019, p.}

165)

Advantages of logical thinking:

1- Searching for the reasons behind the occurrence of things.

2- It is affected by the culture in which the individual lives.

3- Interested in knowing the apparent causes and causes.

4- It aims to reach evidence that confirms or denies hypotheses or alternatives.

5- It is affected by the individual's mental capabilities, advice, experiences, and the environmental conditions surrounding the individual. (Abdulaziz, 2009, p. 54).

* Terms of logical thinking:

1- Sufficiency: What is meant is that the perceptions chosen by the thinker must be preliminary or that he cheats and searches for other perceptions.

2- Judgments: Reflexive reasoning shall be firm if the preliminary issues are compatible, that is, they do not lead to a contradiction later.

3- Independence of ideas: The primary issues are independent if they are specific and do not need other issues.

4- Brevity: Cases are brief when their number is reduced to the smallest number possible.

5- Testimony: Ideas are testicles if they include many theories.

Previous studies :

First: - Special studies in the training program:

1- Abu Awad and Intisar 2011 study

This study was conducted in Jordan and aimed at investigating the impact of a training program based on the creative solution of problems in a sample consisting of (60) students from the seventh grade in Amman schools, divided into two groups, one experimental and the other control, and the parity of the two groups was verified before implementing the training program. Using the pre-test in training crossthinking, the post-test in cross-thinking was applied to the students of the two groups, and the results of the study revealed a statistically significant effect of the training program based on creative problem-solving in each skill of crossthinking skills. (Abu Awad and Intisar, 2011, p. 70).

As for the current study, it is based on a training program based on active learning strategies in the objectives. The sample was students of the College of Basic Education - University of Babylon.

Second: the special study in logical thinking.

1- Abu Ghaly's study (2010).

This study was conducted in Palestine at Gaza University aimed at identifying the effect of employing a strategy (think, marry, share) on developing logical thinking skills in science on the sample of basic eighth grade students. The preand post-logical reasoning test was used on the research sample and using statistical methods. The appropriate results were the superiority of the experimental group over the control group students in the test of logical thinking skills.

As for the current study only, it was based on targeting the logical thinking test on students of the College of Basic Education, the experimental group of (40). The researcher will use the appropriate statistical means and will extract the appropriate results.

* Benefit from previous studies:

1- Knowledge of the theoretical background of the research during previous studies.

2- Knowing the tests that dealt with logical thinking skills.

3- Knowing the necessary steps for parity between the two research groups.

4- See the statistical means and benefit from them. 
5- Knowing the necessary procedures for building and preparing the training program.

\section{Chapter III}

First: Research Methodology:

The researcher adopted the experimental method with partial control because it is the appropriate method for her research procedures, as the experimental method is one of the accurate approaches in the study of some educational phenomena. (Hamza et al., 2016, p. 54).

Second: - experimental design:

The researcher adopted the experimental design of two randomized groups, experimental and control, with partial control and the post-test of logical thinking.

\begin{tabular}{|c|c|c|c|}
\hline $\begin{array}{l}\text { Dependent } \\
\text { variable }\end{array}$ & Independent variable & Valence & the group \\
\hline \multirow{2}{*}{$\begin{array}{l}\text { Logical } \\
\text { reasoning } \\
\text { test }\end{array}$} & $\begin{array}{l}\text { The training program is based } \\
\text { on active learning strategies }\end{array}$ & 1- Intelligence test & $\begin{array}{l}\text { Experimental } \\
\text { group }\end{array}$ \\
\hline & $\begin{array}{l}\text { They were not subject to the } \\
\text { program }\end{array}$ & 2- Logical thinking test & Control group \\
\hline
\end{tabular}

Planner (1)

Experimental design

Third: the research community and its sample:

1- Research Society:

The research community is summarized to students in the science department / all branches / fourth stage / college of basic education / university of Babylon, who number (210) students for the academic year 2019/2020.

2- The research sample:

The research was limited to the (80) students, Department of Science / Chemistry Branch / Fourth Stage, College of Basic Education /

Table (1)

The results of the T-test for students of the two groups of research in the intelligence variable

\begin{tabular}{|c|c|c|c|c|c|c|c|}
\hline \multirow{2}{*}{$\begin{array}{l}\text { Statistical } \\
\text { significance } \\
\text { at the level } \\
0.05\end{array}$} & \multicolumn{2}{|c|}{ Value $t$} & \multirow{2}{*}{$\begin{array}{l}\text { Degree } \\
\text { of free }\end{array}$} & \multirow{2}{*}{$\begin{array}{l}\text { standard } \\
\text { deviation }\end{array}$} & \multirow[t]{2}{*}{ SMA } & \multirow{2}{*}{$\begin{array}{l}\text { No. of } \\
\text { student }\end{array}$} & \multirow[t]{2}{*}{ the group } \\
\hline & table & calculate & & & & & \\
\hline \multirow[t]{2}{*}{$\begin{array}{l}\text { Not sign } \\
\text { Statistical }\end{array}$} & \multirow[t]{2}{*}{1.99} & \multirow[t]{2}{*}{0.43} & \multirow[t]{2}{*}{78} & 8.49 & 34.625 & 40 & $\begin{array}{l}\text { Experimental } \\
\text { group }\end{array}$ \\
\hline & & & & 7.81 & 33.85 & 40 & $\begin{array}{l}\text { Control } \\
\text { group }\end{array}$ \\
\hline
\end{tabular}

2- The pre-logical reasoning test:

Table (2)

Results of the T-test for students of both groups, searching for the logical reasoning test

\begin{tabular}{|c|c|c|c|c|c|c|c|}
\hline Statistical & Value & & Degree & standard & SMA & No. of & the group \\
\hline $\begin{array}{l}\text { significance } \\
\text { at the level } \\
0.05\end{array}$ & table & calculate & of free & deviation & & student & \\
\hline
\end{tabular}




\begin{tabular}{|l|l|l|l|l|l|l|l|}
\hline $\begin{array}{l}\text { Not sign } \\
\text { Statistical }\end{array}$ & 2 & 0.52 & 78 & 4.31 & 11.50 & 40 & $\begin{array}{l}\text { Experimental } \\
\text { group }\end{array}$ \\
\cline { 4 - 7 } & & & & 4.33 & 12.01 & 40 & $\begin{array}{l}\text { Control } \\
\text { group }\end{array}$ \\
\hline
\end{tabular}

4- Control of internal variables:

A- Students' feeling that they are under trial:

The researcher's control of this indicator by maintaining the confidentiality of the experiment and not telling the students that they are under the influence of any experiment. I have been able to do so, being a teacher in the science department and studying educational materials in the department in all branches and all stages and the program date has been fixed in the weekly lectures schedule at a rate of ( 2 hours) Weekly and in the department's classrooms.

* Search tool:

Logical reasoning test:

3- Experimental extinction:

It is intended to extinguish the effect generated from leaving or discontinuing some students subject to sessions in the training program, which affects the average group scores and the research was not exposed to such circumstances throughout the duration of the program sessions.

Fifth: Research requirements:

1- Building the training program: Building the program has gone through three phases:

- The planning stage: it included (program title training needs - active learning strategies trainees' characteristics)

- The implementation phase: it included (the general objective, educational objectives, time limit, content, methods, design of activities, material and moral capabilities and support services.

- The evaluation stage: the stage of presenting the program to the arbitrators included review and reevaluation.

Research tool: (Souad Abdullah, 2011, p. 313).

Given that the researcher did not obtain a readymade exam to test logical thinking skills that are compatible with the nature of the university level and the subject in the program to achieve the objectives of this research, the researcher followed the following steps:

A- Determine the areas covered by the test:

The researcher prepared a questionnaire to determine the skills of logical thinking, and it was presented to a number of arbitrators with specialization in the field of education and teaching methods in various universities. In the light of the opinions of the arbitrators, the researcher selected the appropriate skills.

B - Building the test items:

After reviewing the literature, such as a study (Abu Ghaly, 2010 - and Abu Sultan, 2012). The researcher prepared a test of logical thinking skills of the type of essay in proportion to the age of the sample.

C- Test Instructions:

Special instructions were placed for students to answer the test items, explaining how students got to answer accurately.

D - The key to a typical answer:

Key formulas for typical answers to test items.

E - Validate the test:

* Virtual validity :

The researcher presented the logical thinking skills test in its preliminary form to a group of referees with specialization in the field of education and methods of teaching it, and she obtained a fair rate of $(100 \%)$.

* Application of the test to the initial exploratory sample:

The logical thinking skills test was applied to an exploratory sample of (50) students in the science department, biology branch, for the purpose of making sure of the clarity of the paragraphs and test instructions and their diagnosis of the paragraphs.

* Application of the second pilot sample: 
After ensuring the clarity of the test items and determining the required time for the exam, the test was applied to the second exploratory sample consisting of (60) male and female students in the Science Department, Physics Branch, for the purpose of statistical analysis and finding the difficulty rate and the coefficient of excellence.

* Stability of the test: it was by the halfsegmentation method, as well as by the base equation and its stability.

* Application of the logical thinking skills test:

After completing the application of the program on the students of the experimental group for the research, the researcher applied a test of logical thinking skills to the two research groups simultaneously.

Sixthly: - statistical means:

Table (3)

The statistical significance of the two groups of research in the dimensional logical thinking test

\begin{tabular}{|l|l|l|l|l|l|l|l|}
\hline $\begin{array}{l}\text { Statistical } \\
\text { significance } \\
\text { at the level } \\
\mathbf{0 . 0 5}\end{array}$ & \multicolumn{2}{|l|}{ Value t } & Degree & standard \\
of fable & calculate & SMA & $\begin{array}{l}\text { No. of } \\
\text { student }\end{array}$ & the group \\
\hline $\begin{array}{l}\text { sign } \\
\text { Statistical }\end{array}$ & 2 & 3.966 & 78 & 5.595 & 51.01 & 40 & $\begin{array}{l}\text { Experimental } \\
\text { group }\end{array}$ \\
\cline { 4 - 8 } & & & & 6.894 & 44.90 & 40 & $\begin{array}{l}\text { Control } \\
\text { group }\end{array}$ \\
\hline
\end{tabular}

This indicates that there is a statistically significant difference between the results of the two research groups in the dimensional logical reasoning test in favor of the experimental group. In light of this, we reject the null hypothesis. This is consistent with the study (Abu Ghaly, 2010).

Second: - Conclusions:

1- The use of a training program based on active learning strategies has proven effective in increasing logical thinking among students of the College of Basic Education / Department of Science, Experimental Group.

Third: - Recommendations:
The researcher used (Microsoft Excel 2010) and (SPPS)

\section{the fourth chapter}

First: - Presentation and interpretation of results:

For the purpose of verifying the null hypothesis, which states (there is no statistically significant difference at a level of significance (0.05) between the average scores of the students in the experimental group who took the proposed training program and the average scores of the students who did not take it in the logical reasoning test).

Using the T-test for two independent samples and adopting the effect size equation to know the effect of the independent variable (the proposed training program) on the dependent variable (the logical thinking skills test) after applying the test. 
methods and knowing its effect on logical thinking.

\section{Sources :}

[1] Al Butti, Jalal Shantah (2011) Curriculum and Teaching Methods, 1st Edition, Dar Al Fikr Publishers and Distributors, Amman, Jordan.

[2] Abu Sultan, practically Kamal Hussain (2012): Strategy K. W. L in tracking concepts and logical thinking skills in mathematics for ninth grade female students, unpublished MA thesis, Islamic University, College of Education, Gaza, Palestine.

[3] Abu Ghaly, Salim Muhammad (2010), the effect of employing a strategy (think, marry, share) on developing logical thinking skills in science among eighth grade students, unpublished MA thesis, Islamic University, College of Education, Gaza, Palestine.

[4] Badir, Karimat Muhammad, (2012) Active Learning, 2nd Edition, Dar Al Masirah for Publishing and Distribution, Amman, Jordan.

[5] Al-Janabi, Farman Qaht Rahima, (2018) active learning and its effectiveness in developing teaching skills, 1st edition, Dar Al-Sadiq Cultural Foundation, Al-Hilla, Iraq.

[6] Good, Saeed Souad (2008) The Psychology of Thinking and Self-awareness, 1st Edition, Modern Book Science for Publishing and Distribution, Amman, Jordan.

[7] Hamzah and others, Hamid Muhammad, Nasreen Al-Sultani, and Ibtisam Jaafar (2016) Research Methods in Education and Psychology, 1st Edition, Al-Radwan Publishing and Distribution House, Amman, Jordan.

[8] Rifai, Aqeel Mahmoud (2012): Active Learning (concept, strategy and evaluation of learning outcomes, 1st Edition, New University Publishing House, Alexandria, Egypt.

[9] Zayed and others, Saad Ali, Daoud Abdel Salam Sabry, Muhammad Hadi (2013) General Teaching Methods, 1st Edition, Safaa House for Publishing and Distribution, Amman, Jordan.

[10] HE, Jawdat Ahmad Abdullah (2011) The Contemporary School Curriculum, 6th Edition,
Dar Al Fikr, Publisher and Distributors, Amman, Jordan.

[11] Sheikh, Ghada Sharif Abdel Hamza (2015) Building a training program according to visual learning strategies for students - teachers in the Department of General Sciences and its impact on their teaching performance and visual thinking for their students, (PhD thesis), College of Education for Pure Sciences, Ibn Al Haytham, University of Babylon, Iraq .

[12] Attia, Mohsen Ali (2016) Learning, Patterns and Modern Models, 1st Edition, Dar Al-Safa for Publishing and Distribution, Amman, Jordan.

[13] Mohsen Ali, 2018) Communication Technology in Education, 1st edition, Dar AlManhaj for Publishing and Distribution, Amman, Jordan.

[14] Awwad, Yusef Dhiab, and Majdi Ali Zamil, (2010): active learning, the growth of an effective educational educational philosophy, 1st edition, Dar Manhaj for Publishing and Distribution, Amman, Jordan. 